\title{
NGHIÊN CỨU ỨNG DỤNG MÔ HİNH HÓA ĐÁNH GIÁ XU THẾ CỦA NGậP LỤT VÀ XÂM NHẬP MặN TRONG BỐI CẢNH BIẾN ĐỔI KHÍ HậU: NGHIÊN CỨU THÍ ĐIỂM TạI THÀNH PHỐ HỔ CHÍ MINH
}

\author{
Vũ Thùy Linh ${ }^{1,2}$, Nguyễn Duy Liêm ${ }^{3}$ Hồ Minh Dũng ${ }^{2,4}$, Nguyễn Kim Lợi ${ }^{3}$
}

Tóm tắt: Nghiên cứu tích hợp mô hình SWAT và HEC-RAS nhằm mô phỏng, phân tích xu thế ngập lụt và xâm nhập mặn cho thành phố Hồ Chí Minh theo kịch bản cơ sở (1980-2006) và kịch bản biến đổi khi hậu RCP 4.5 (2016-2035). Kết quả hiệu chỉnh, kiểm định mô hình SWAT về lưu lương dòng chảy trên lưu vực sông Đồng Nai tại ba trạm Phước Hòa, Tà Lài và Tà Pao và mô hình HECRAS về mưc nước, độ mặn tại hai trạm Phú An và Nhà Bè ở mức chấp nhận. Tương tự, đối với với mức chấp nhận. Tù bộ mô hình SWAT, HEC-RAS, kết hợp với phân tích xu huớng bằng kiểm định phi tham số Mann-Kendall và độ dốc Theil-Sen, đã cho thấy trong giai đoạn 1980-2006, ngập lut, xâm nhập mặn chủ yếu có xu hướng không rõ rệt hoặc it rõ rệt. Tuy nhiên, sang kịch bản BĐKH RCP 4.5 2016-2035, cả hai hiện tuợng này có tỉ lẹ xu hương rõ rệt hoạc rất rõ rệt gia tăng tại các khu vưc ven sông, kênh rạch tại thành phố. Đặc biệt, huyện Cần Giờ là khu vự bị ảnh hưởng nạng nề nhất. Với nhũ̃ng phát hiện này, có thể cung cấp thông tin hữu ích cho công tác quản lý, quy hoạch sư dụng đất, thủy lợi, cấp nước trên địa bàn TPHCM trong bối cảnh BĐKH ngày càng diến biến phức tạp, khó lường.

Từ khóa: Biến đổi khi hậu, HEC-RAS, ngập lụt, SWAT, thành phố Hồ Chí Minh, xâm nhập mặn.

Ban biên tập nhận bài: 11/12/2019 Ngày phản biện xong: 12/12/2019 Ngày đăng bài: 20/12/2019

\section{Mở đầu}

Thành phố Hồ Chí Minh (TPHCM) nằm trong vùng chuyển tiếp giữa miền Đông Nam bộ và đồng bằng sông Cửu Long với phần phía $\mathrm{Nam}$ tiếp giáp biển Đông. Địa hình thấp dần từ Bắc xuống Nam và từ Đông sang Tây, với khoảng $60 \%$ diện tích thành phố ở độ cao từ 1 mét trở lên so với mực nước biển (ADB, 2010). Phần lớn diện tích của TPHCM nằm trên vùng đầm lầy, bị chia cắt bởi mạng lưới sông ngòi, kênh rạch phức tạp. Vị trí địa lý và đặc điểm địa hình như trên làm cho thành phố rất nhạy cảm với ngập lụt và xâm nhập mặn [7].

Dưới tác động của triều cường, mưa lớn và nước dâng do bão, khoảng 53\% diện tích, 12\% dân số của thành phố thường xuyên bị ảnh hưởng bởi ngập lụt [2]. Tình trạng này càng trở nên trầm trọng khi có sự cộng hưởng từ biến đổi khí hậu (BĐKH). Theo ước tính, nếu mực nước biển dâng $100 \mathrm{~cm}$, khoảng 17,84\% diện tích TPHCM có nguy cơ bị ngập [3]. Ngoài ra, các hoạt động xây dựng ở vùng đầm lầy và ven sông khiến gia tăng mực nước sông, kéo theo khoảng 70\% diện tích đất nông nghiệp và $50 \%$ nhà máy xử lý nước mặt và nước ngầm trên địa bàn thành phố đối mặt với nguy cơ nhiễm mặn và ngập lụt $[2,13]$. Như vậy, có thể thấy ngập lụt, xâm nhập mặn tại TPHCM không chỉ do BĐKH mà còn do mô hình phát triển đô thị thiếu bền vững [5]. Những thách thức môi trường này sẽ ngày càng rõ ràng và tác động tiêu cực đến sự phát triển kinh tế-xã hội của TPHCM nếu không có những giải pháp ứng phó kịp thời, hiệu quả.

Một số nghiên cứu về dòng chảy các tiểu lưu vực thuộc lưu vực Đồng Nai đã được thực hiện nhằm nghiên cứu mô phỏng lưu lượng dòng

\footnotetext{
'Sở Tài nguyên và Môi trường Thành phố Hồ Chí Minh

${ }^{2}$ Viện Môi trương và Tài nguyên - ĐH Quốc gia Thành phố Hồ Chí Minh

${ }^{3}$ Trưòng Đại học Nông Lâm Thành phố Hồ Chí Minh

${ }^{4}$ Viện Khoa học và Công nghệ Tính toán

Email:ngkloi@hcmuaf.edu.vn 
chảy tại lưu vực và đánh giá mức độ phù hợp khi ứng dụng mô hình SWAT tiêu biểu như nghiên cứu của Nguyễn Duy Liêm và Nguyễn Kim Lợi (2012) [10], Nguyễn Thị Ngọc Quyên và cộng sự (2013) [12]. Đối với khu vực TPHCM, Nigel Downes (2010) đã sử dụng công cụ GIS nhằm đánh giá các rủi ro ngập lụt cho các khu vực trọng điểm dựa trên Quy hoạch sử dụng đất TP.HCM đến năm 2020 để đưa ra các khuyến nghị nhằm thích ứng với BĐKH [9] . Bên cạnh đó PGS.TS. Nguyễn Kỳ Phùng cũng sử dụng mô hình SIMCLIM, tác giả tính toán, xây dựng kịch bản $\mathrm{BĐKH}$ và nước biển dâng cho TP.HCM, đánh giá diện tích ngập lụt và từ đó đưa ra các đánh giá tác động đối với dân cư xã hội, doanh nghiệp và các loại đất [11].

Mặc dù đã có những nghiên cứu đánh giá mức độ ngập lụt của TPHCM, tuy nhiên chưa có nghiên cứu đánh giá ảnh hưởng tổng thể dòng chảy từ lưu vực Đồng Nai cũng như tác động của BĐKH đến xu thế ngập và xâm nhập mặn đối với TPHCM. Do đó, nghiên cứu thực hiện với mục tiêu bao gồm: (1) Mô phỏng ngập lụt, xâm nhập mặn tại TPHCM trong giai đoạn 19802006, (2) Phân tích xu hướng ngập lụt, xâm nhập mặn tại TPHCM theo kịch bản cơ sở (19802006) và kịch bản BĐKH RCP 4.5 2016-2035, (3) Phân vùng BĐKH cho khu vực nghiên cứu dựa trên ngập lụt, xâm nhập mặn theo kịch bản cơ sở (1980-2006) và kịch bản $\mathrm{BĐKH} \mathrm{RCP} 4.5$ 2016-2035.

\section{Dũ liệu và phương pháp}

\subsection{Thu thập dĩ liệu}

Dữ liệu cần thiết cho nghiên cứu được mô tả chi tiết ở Bảng 1 .

Bảng 1. Dũ liệu đầu vào cho nghiên cúu

\begin{tabular}{|c|c|c|}
\hline Dữ liệu & Mô tả & Nguồn thu thập \\
\hline Bản đồ địa hình & $\begin{array}{l}\text { - Mô hình độ cao số (DEM), độ phân giải không } \\
\text { gian } 30 \text { m, lưu vực sông Đồng Nai. } \\
\text { - Bản đồ địa hình, tỉ lệ 1:50.000, TPHCM, thể } \\
\text { hiện lớp hành chính, giao thông, thủy hệ, địa } \\
\text { hình. }\end{array}$ & $\begin{array}{l}\text { - ASTER GDEM v0002, } \\
\text { METI/NASA } \\
\text { - Sở Tài nguyên và Môi } \\
\text { trường TPHCM }\end{array}$ \\
\hline Bản đồ sử dụng đất & $\begin{array}{l}\text { - Năm 2000, lưu vực sông Đồng Nai, thể hiện } \\
\text { các loại hình sử dụng đất. } \\
\text { - Năm 2005, tỉ lệ 1:50.000, TPHCM, thể hiện } \\
\text { các loại hình sử dụng đất. }\end{array}$ & $\begin{array}{l}\text { - Viện Quy hoạch Thủy lợi } \\
\text { miền Nam } \\
\text { - Sở Tài nguyên và Môi } \\
\text { trường TPHCM }\end{array}$ \\
\hline Bản đồ thổ nhưỡng & Tỉ lệ 1:50.000, TPHCM, thể hiện các loại đất. & $\begin{array}{l}\text { Sở Tài nguyên và Môi } \\
\text { trường TPHCM }\end{array}$ \\
\hline $\begin{array}{l}\text { Cơ sở dữ liệu đất của } \\
\text { FAO }\end{array}$ & $\begin{array}{l}\text { Các thông số đất đầu vào SWAT phân theo } \\
\text { thành phần cơ giới với } 1 \text { tầng đất. }\end{array}$ & FAO (2003) $[4]$ \\
\hline Số liệu khí tượng & $\begin{array}{l}\text { - } 10 \text { điểm đo mưa, } 10 \text { trạm khí tượng, giai đoạn } \\
\text { 1980-2006, lưu vực sông Đồng Nai, thể hiện số } \\
\text { liệu đo lượng mưa, nhiệt độ không khí tối cao, } \\
\text { tối thấp theo ngày. } \\
\text { - } 12 \text { điểm đo mưa, } 2 \text { trạm khí tượng, giai đoạn } \\
\text { 1980-2006, TPHCM, thể hiện số liệu đo lượng } \\
\text { mưa theo ngày. }\end{array}$ & $\begin{array}{l}\text { Đài Khí tượng Thủy văn } \\
\text { Tây Nguyên, } \\
\text { Đài Khí tượng Thủy văn } \\
\text { Nam Bộ }\end{array}$ \\
\hline Số liệu thủy văn & $\begin{array}{l}\text { - } 3 \text { trạm, giai đoạn 1980-2006, lưu vực sông } \\
\text { Đồng Nai, thể hiện số liệu đo lưu lượng dòng } \\
\text { chảy theo tháng. } \\
\text { - } 2 \text { trạm, giai đoạn 1990-2006, TPHCM, thể hiện } \\
\text { số liệu đo mực nước theo tháng. }\end{array}$ & $\begin{array}{l}\text { Đài Khí tượng Thủy văn } \\
\text { Nam Bộ }\end{array}$ \\
\hline Số liệu hải văn & $\begin{array}{l}\text { Tram Vũng Tàu, giai đoạn 1990-2006, thể hiện } \\
\text { số liệu đo mực nước biển theo tháng. }\end{array}$ & $\begin{array}{l}\text { Đài Khí tượng Thủy văn } \\
\text { Nam Bộ }\end{array}$ \\
\hline Số liệu độ mặn & $\begin{array}{l}2 \text { trạm, năm 2006, TPHCM, thể hiện số liệu đo } \\
\text { độ mặn theo ngày. }\end{array}$ & $\begin{array}{l}\text { Sở Tài nguyên và Môi } \\
\text { trường TPHCM }\end{array}$ \\
\hline Số liệu BĐKH & $\begin{array}{l}\text { Kịch bản RCP } 4.5 \text { giai đoạn } 2016-2035 \text {, lưu vực } \\
\text { sông Đồng Nai, thể hiện số liệu dự tính khí hậu } \\
\text { theo mùa (thay đồi lượng mưa, nhiệt độ không } \\
\text { khí trung bình). }\end{array}$ & $\begin{array}{l}\text { Bộ Tài nguyên và Môi } \\
\text { trường (2016) }\end{array}$ \\
\hline $\begin{array}{l}\text { Số liệu nồng độ } \mathrm{CO}_{2} \\
\text { trong khí quyền }\end{array}$ & $\begin{array}{l}\text { Thời điểm 2006, 2035, phạm vi toàn cầu, thể } \\
\text { hiện số liệu quan trắc, dự tính nồng độ } \mathrm{CO}_{2} \\
\text { trong khí quyến vào năm 2006, } 2035 \text { tương ứng } \\
\text { là } 378 \text { ppm, } 448 \text { ppm. }\end{array}$ & IPCC (2013) [6] \\
\hline Ảnh vệ tinh Landsat 8 & $\begin{array}{l}\text { Xử lý mức L1TP (hiệu chỉnh bức xạ, hình học), } \\
\text { thu nhận } 6 / 1 / 2017,14 / 2 / 2017,31 / 10 / 2018 \text {, } \\
\text { TPHCM. }\end{array}$ & U.S. Geological Survey \\
\hline
\end{tabular}


BÀI BÁO KHOA HỌC

\subsection{Tiến trình thục hiện}

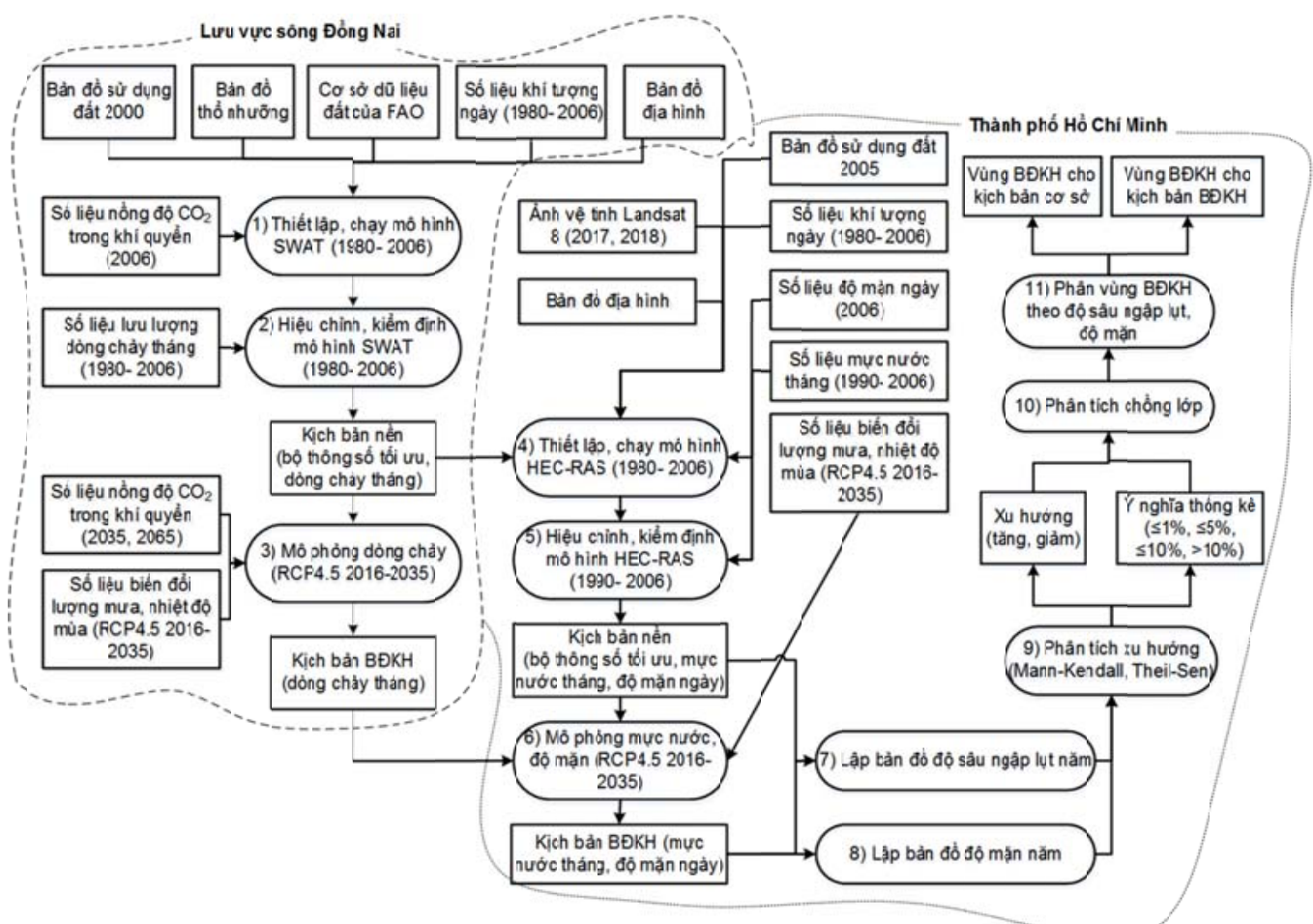

Hình 1. Tiến trình phân vùng BĐKH dựa trên ngập lụt, xâm nhập mặn

Tiến trình thực hiện của nghiên cứu được thể hiện như Hình 1, với 11 bước.

Bước 1: Từ bản đồ sử dụng đất năm 2000, thổ nhưỡng, cơ sở dữ liệu đất của FAO, số liệu khí tượng ngày (1980-2006), bản đồ địa hình, số liệu nồng độ CO2 năm 2006 trong khí quyển, thiết lập, chạy mô hình SWAT cho lưu vực sông Đồng Nai trong giai đoạn 1980-2006.

Bước 2: Hiệu chỉnh, kiểm định mô hình SWAT sử dụng số liệu quan trắc lưu lượng dòng chảy theo tháng cho lưu vực sông Đồng Nai trong giai đoạn 1980-2006; kết quả đạt được là kịch bản nền SWAT với bộ thông số tối ưu và lưu lượng dòng chảy theo tháng.

Bước 3: Từ kịch bản nền SWAT, số liệu nồng độ $\mathrm{CO} 2$ trong khí quyển năm 2035 và số liệu biến đổi lượng mưa, nhiệt độ theo mùa (RCP 4.5 2016-2035), tiến hành mô phỏng lưu lượng dòng chảy ứng với kịch bản BĐKH RCP 4.5 20162035, cho ra kết quả là lưu lượng dòng chảy theo tháng ứng với kịch bản $\mathrm{BĐKH.}$

Bước 4: Dựa trên kịch bản nền SWAT, ảnh vệ tinh Landsat $8(2017,2018)$, bản đồ địa hình, sử dụng đất năm 2005, số liệu khí tượng ngày (1980-2006), số liệu mực nước tháng (19902006), số liệu độ mặn ngày (2006), thiết lập, chạy mô hình HEC-RAS cho TPHCM trong giai đoạn 1980-2006.

Bước 5: Hiệu chỉnh, kiểm định mô hình HEC-RAS sử dụng số liệu quan trắc mực nước theo tháng, độ mặn theo ngày cho TPHCM trong giai đoạn 1990-2006; kết quả đạt được là kịch bản nền HEC-RAS với bộ thông số tối ưu và mực nước theo tháng, độ mặn theo ngày.

Bước 6: Từ kịch bản nền HEC-RAS, số liệu biến đổi lượng mưa, nhiệt độ theo mùa (RCP 4.5 2016-2035) và lưu lượng dòng chảy theo tháng ở kịch bản BĐKH mô phỏng bởi SWAT, tiến hành mô phỏng mực nước, độ mặn ứng với kịch bản BĐKH RCP 4.5 2016-2035, cho ra kết quả là mực nước theo tháng, độ mặn theo ngày ứng với kịch bản BĐKH.

Bước 7: Lập bản đồ độ sâu ngập lụt theo năm trong giai đoạn 1980-2006 và kịch bản $\mathrm{BĐKH}$ RCP 4.5 2016-2035.

Bước 8: Lập bản đồ độ mặn theo năm trong 
giai đoạn 1980-2006 và kịch bản $\mathrm{BĐKH} \mathrm{RCP}$ 4.5 2016-2035.

Bước 9: Phân tích xu hướng của chuỗi thời gian độ sâu ngập lụt, độ mặn theo năm trong giai đoạn 1980-2006 và kịch bản BĐKH RCP 4.5 2016-2035 bằng phương pháp kiểm định phi tham số Mann-Kendall và độ dốc Theil-Sen.

Bước 10: Chồng lớp kết quả phân tích xu hướng độ sâu ngập lụt, độ mặn (tăng, giảm) với mức ý nghĩa thống kê $(\leq 1 \%, \leq 5 \%, \leq 10 \%,>$ $10 \%$ ) trong giai đoạn 1980-2006 và kịch bản BĐKH RCP 4.5 2016-2035.

Bước 11: Phân vùng BĐKH theo độ sâu ngập lụt, độ mặn cho giai đoạn 1980-2006 và kịch bản BĐKH RCP 4.5 2016-2035.

\subsection{Hiệu chỉnh, kiểm định mô hình SWAT}

Nghiên cứu tiến hành hiệu chỉnh, kiểm định lưu lượng dòng chảy cho lưu vực sông Đồng Nai với các bước thực hiện trong công cụ ArcSWAT, phần mềm SWAT-CUP như Hình 2 với 5 bước.

Bước 1: Biên tập dữ liệu đầu vào: Các dữ liệu đầu vào cần thiết cho quá trình mô phỏng dòng chảy trong mô hình SWAT được biên tập theo định dạng dữ liệu không gian, thuộc tính của mô hình. Cụ thể, dữ liệu DEM được xây dựng từ bản đồ địa hình theo phương pháp nội suy Topo to Raster với độ phân giải không gian 20 m (xem Hình 3a). Tiếp theo, dựa trên DEM, tính toán, phân cấp độ dốc (4 cấp với cận trên lần lượt là 14\%, 27\%, 47\%, 391\%) (xem Hình 3b). Đối với dữ liệu sử dụng đất, từ bản đồ sử dụng đất 2000, tiến hành chuyển mã loại đất theo SWAT (xem Hình 3c). Sau đó, chuyển dữ liệu sang dạng raster và tạo bảng tra dạng ASCII. Đối với dữ liệu thổ nhưỡng, từ bản đồ thổ nhưỡng, cơ sở dữ liệu đất của $\mathrm{FAO}$, tiến hành biên tập các thông số đất theo SWAT (xem Hình 3d). Sau đó, chuyển dữ liệu sang dạng raster và tạo bảng tra dạng ASCII. Đối với dữ liệu thời tiết, từ số liệu khí tượng thu thập, tiến hành phân loại dữ liệu thành hai loại: thời tiết tổng quát (11 trạm), thời tiết thành phần (lượng mưa ngày: 20 trạm; nhiệt độ không khí tối cao, tối thấp ngày, độ ẩm không khí tương đối ngày, bức xạ Mặt Trời ngày, tốc độ gió ngày: 11 trạm) (xem Hình 4). Sau đó, biên tập dữ liệu cho từng loại.

Bước 2: Thiết lập mô hình: Từ dữ liệu đầu vào đã biên tập, tiến hành thiết lập mô hình SWAT theo trình tự: phân chia lưu vực, phân tích đơn vị thủy văn, nhập số liệu thời tiết, tạo tập tin đầu vào, khai báo nồng độ $\mathrm{CO} 2$ trong khí quyển năm 2006 (378 ppm) thuộc tập tin tiểu lưu vực (*.bsn).

Bước 3: Chạy mô hình: Khai báo giai đoạn mô phỏng (1980-2006), tần suất in ấn tập tin đầu ra theo tháng, số lượng biến đầu ra (lưu lượng dòng chảy trong tập tin output.rch). Sau đó, kích hoạt tập tin thực thi, chạy mô hình SWAT.

Bước 4: Hiệu chỉnh mô hình: Đánh giá độ tin cậy của kết quả mô phỏng lưu lượng dòng chảy giai đoạn 1980-2006 tại trạm Phước Hòa (sông Bé), Tà Lài (sông Đồng Nai), Tà Pao (sông La Ngà) với bộ thông số mặc định sử dụng các chỉ số thống kê NSE, PBIAS (xem Bảng 2). Đồng thời, phân tích, lựa chọn sơ bộ thông số cần hiệu chỉnh (ảnh hưởng đến dòng chảy mặt, dòng chảy ngầm). Sau đó, phân tích độ nhạy nhằm lựa chọn bộ thông số chi phối mạnh nhất/ nhạy nhất đến dòng chảy trên lưu vực (nghĩa là có trị tuyệt đối t-Stat lớn nhất và mang ý nghĩa thống kê với pvalue $\leq 5 \%$ ), từ đó, tiến hành hiệu chỉnh lưu lượng dòng chảy theo tháng (1980-1986 tại trạm Phước Hòa, 1985-1995 tại trạm Tà Lài, 19801990 tại trạm Tà Pao) sử dụng thuật toán tối ưu SUFI-2 (Abbaspour, 2015). Nếu chấp nhận kết quả mô phỏng (tức là thỏa mãn NSE $>0,5$, PBIAS $< \pm 25 \%$ ) thì kết thúc hiệu chỉnh, chuyển sang kiểm định. Ngược lại, tiếp tục hiệu chỉnh.

Bước 5: Kiểm định mô hình: Sử dụng bộ thông số tối ưu đã xác định ở bước hiệu chỉnh, tiến hành kiểm định lưu lượng dòng chảy theo tháng (1987-1994 tại trạm Phước Hòa, 19962006 tại trạm Tà Lài, 1991-2000 tại trạm Tà Pao). Nếu chấp nhận kết quả mô phỏng (tức là thỏa mãn NSE $>0,5$, PBIAS $< \pm 25 \%$ ) thì kết thúc kiểm định. Ngược lại, tiếp tục quay lại bước hiệu chỉnh. 


\section{BÀI BÁO KHOA HỌC}

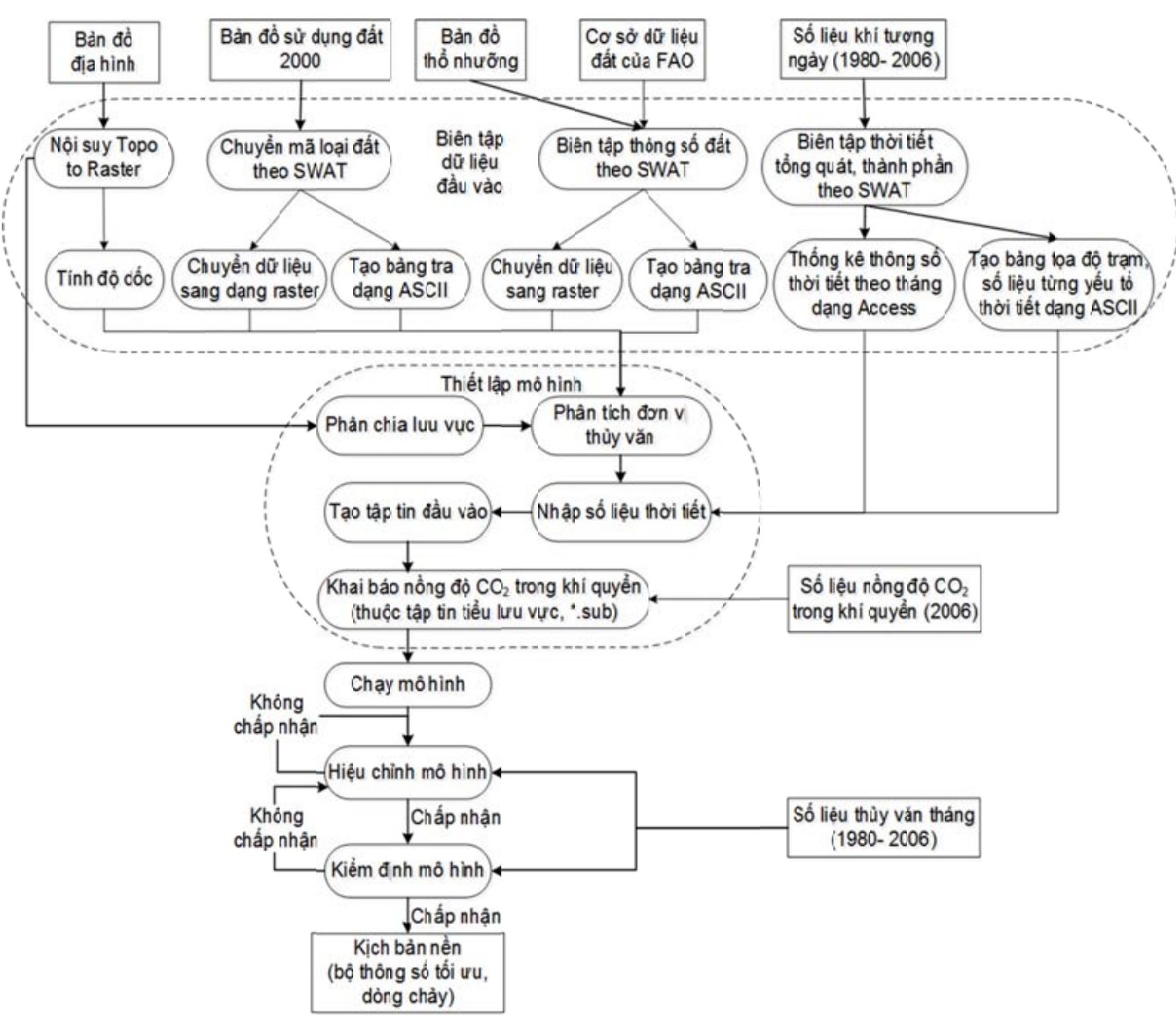

Hình 2. Tiến trình hiệu chỉnh, kiểm định luu luợng dòng chảy

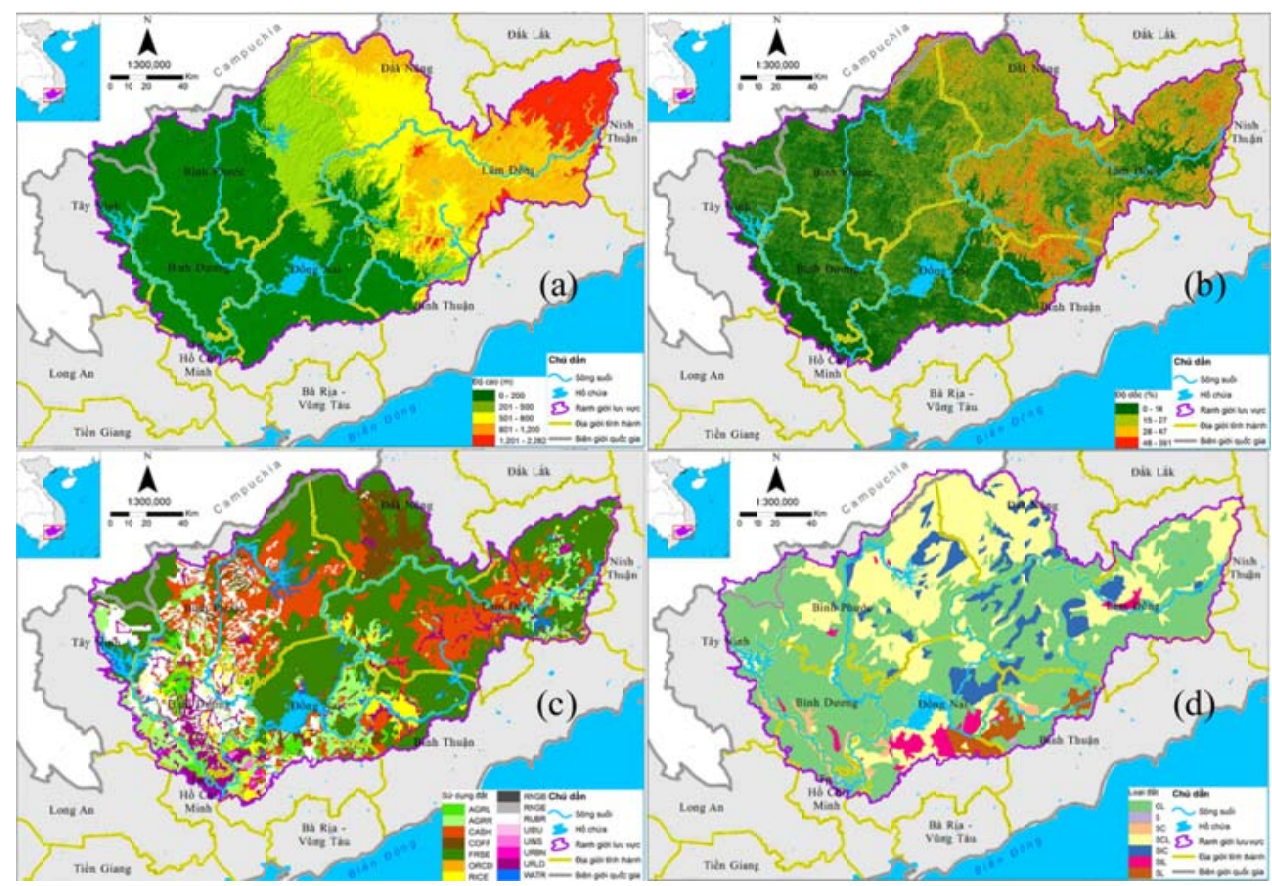

Hình 3. (a) Dũ liệu DEM; (b) Dũ liệu độ dốc; (c) Dũ liệu sử dụng đất 2000 theo yêu cầu của mô hình SWAT; (d) Dũ liệu thổ nhương theo yêu cầu của SWAT trên lưu vực sông Đồng Nai 


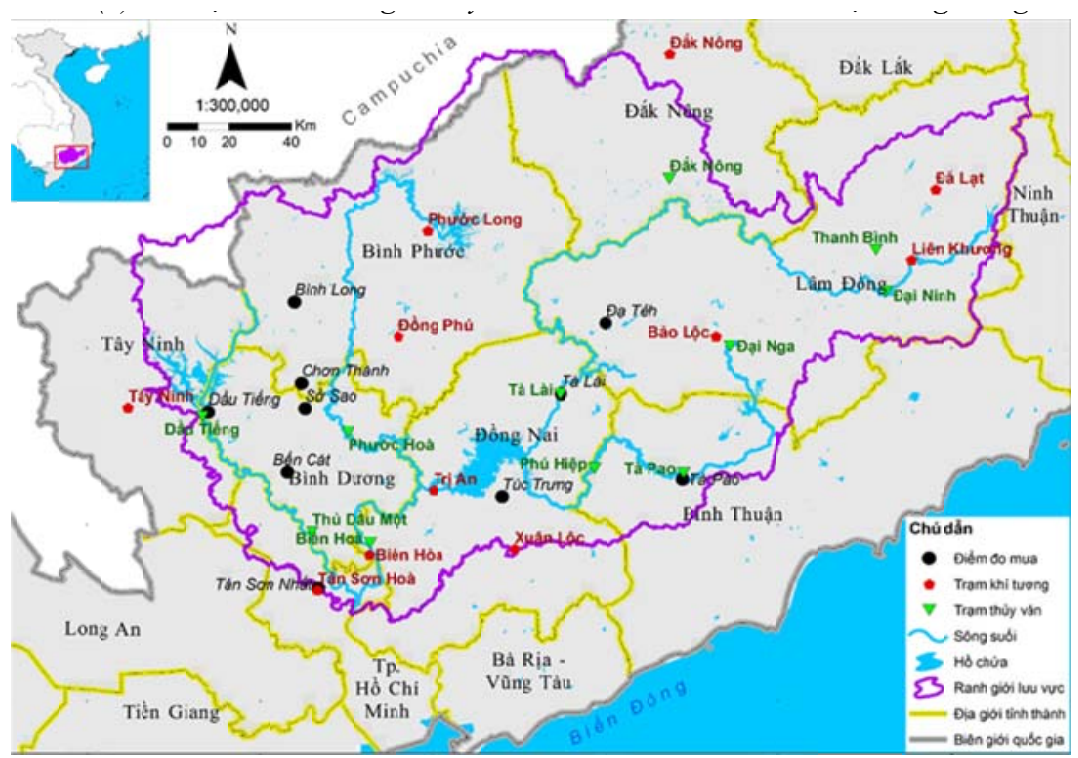

Hình 4. Mạng lưới điểm đo mưa, trạm khí tượng, thủy văn trên lưu vục sông Đồng Nai

Bảng 2. Phân cấp mức độ hiệu quả của mô hình

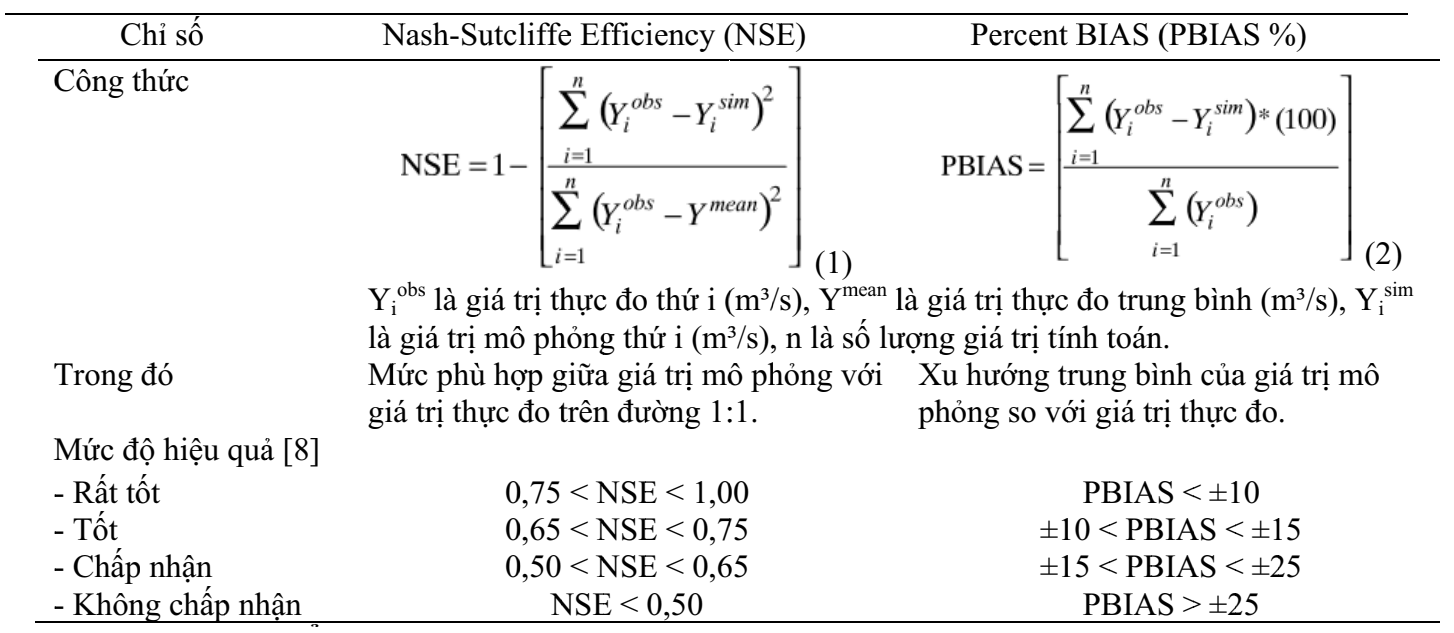

\subsection{Hiệu chỉnh, kiểm định mô hình HEC-} $R A S$

Nghiên cứu tiến hành hiệu chỉnh, kiểm định mực nước, độ mặn cho khu vực TPHCM với các bước thực hiện trong phần mềm HEC-RAS như hình 5 với năm bước.

Bước 1: Biên tập dữ liệu đầu vào: Các dữ liệu đầu vào cho quá trình mô phỏng mực nước, độ mặn trong HEC-RAS được biên tập theo định dạng dữ liệu không gian, thuộc tính của mô hình. Cụ thể, dữ liệu DEM được xây dựng từ bản đồ địa hình theo phương pháp nội suy Topo to Raster với độ phân giải không gian 20 m (xem Hình $6 a$ ). Đối với dữ liệu sử dụng đất, từ bản đồ sử dụng đất 2005, tiến hành gán hệ số nhám (xem Hình 6b). Đối với số liệu khí tượng, tiến hành trích xuất số liệu mưa theo ngày tại 12 điểm đo mưa, 2 trạm khí tượng. Sau đó, sử dụng thuật toán nội suy Thiessen, phân vùng mưa cho từng điểm đo mưa, trạm khí tượng (xem Hình 6c). Tiếp theo, dựa trên kết quả ước tính độ sâu từ ảnh vệ tinh Landsat 8 , tiến hành cập nhật giá trị độ cao cho mạng lưới sông suối (xem Hình 6d). Đồng thời, biên tập dữ liệu theo định dạng của HEC-RAS.

Bước 2: Thiết lập mô hình: Từ dữ liệu đầu vào đã biên tập, tiến hành thiết lập HEC-RAS theo trình tự: thiết lập lưới tính (20 m), xác định 


\section{BÀI BÁO KHOA HỌC}

vị trí biên (biên trên tại vị trí sông Đồng Nai, sông Sài Gòn bắt đầu chảy vào địa phận TPHCM; biên dưới là biển Đông), nhập số liệu điều kiện biên (lưu lượng dòng chảy mô phỏng từ SWAT tại hai biên trên, mực nước quan trắc tại trạm hải văn Vũng Tàu, lượng mưa cho lưới tính), điều kiện ban đầu (mực nước lưới tính bằng 0 ), số liệu đo mặn (hệ số phân tán $50 \mathrm{~m}^{2} / \mathrm{s}$, nồng độ mặn $\mathrm{g} / \mathrm{L}$ ).

Bước 3: Chạy mô hình: Khai báo giai đoạn mô phỏng (1980-2006), tần suất tính toán theo ngày, tần suất in ấn tập tin đầu ra theo ngày. Sau đó, chạy mô hình HEC-RAS.

Bước 4: Hiệu chỉnh mô hình: Đánh giá độ tin cậy của kết quả mô phỏng mực nước (19902006), độ mặn (2006) theo ngày tại hai trạm thủy văn Phú An, Nhà Bè (xem Hình 12) với bộ thông số mặc định sử dụng chỉ số thống kê NSE. Sau đó, tiến hành hiệu chỉnh mực nước theo tháng (1990-1997), độ mặn theo ngày (ba tháng, 24/2006). Nếu chấp nhận kết quả mô phỏng (tức là thỏa mãn NSE > 0,5) thì kết thúc hiệu chỉnh, chuyển sang kiểm định. Ngược lại, tiếp tục hiệu chỉnh.

Bước 5: Kiểm định mô hình: Sử dụng bộ thông số tối ưu đã xác định ở bước hiệu chỉnh, tiến hành kiểm định mực nước theo tháng (19982006), độ mặn theo ngày (ba tháng, 5-7/2006). Nếu chấp nhận kết quả mô phỏng (tức là thỏa mãn NSE > 0,5) thì kết thúc kiểm định. Ngược lại, tiếp tục quay lại bước hiệu chỉnh.

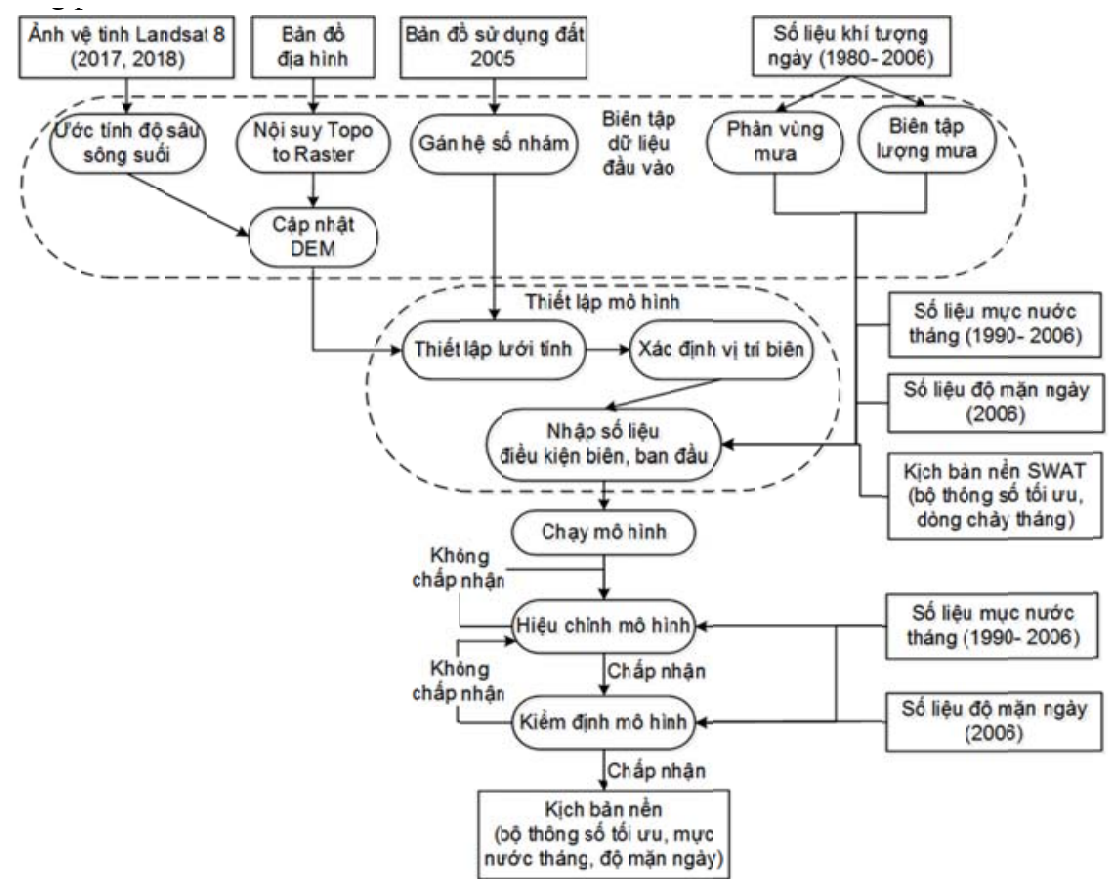

Hình 5. Tiến trình hiệu chỉnh, kiểm định mưc nước, độ mặn 


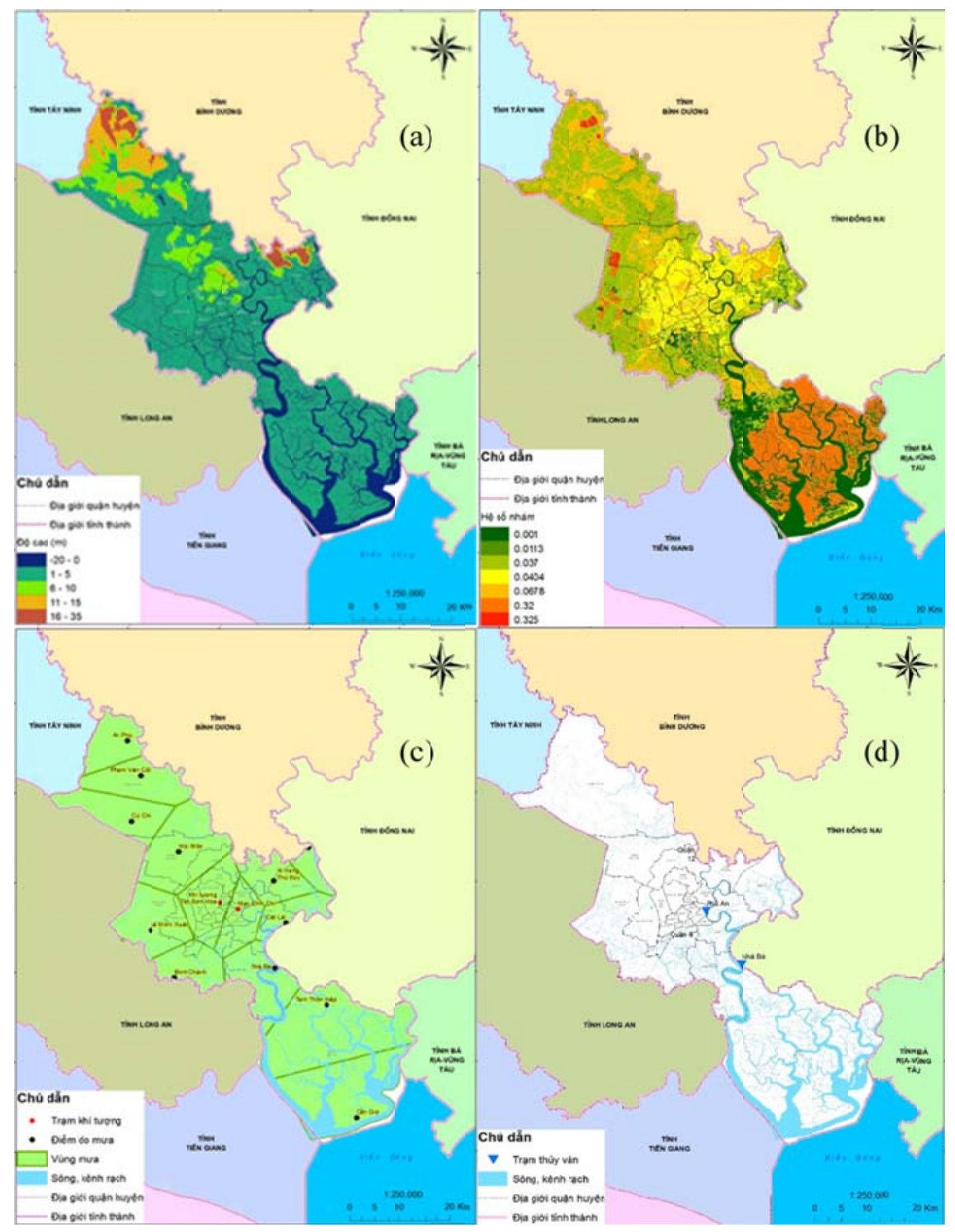

Hình 6. (a) Dũ liệu DEM; (b) Hệ số nhám theo bản đồ sủ dụng đất năm 2005; (c) Phân vùng mưa theo thuật toán nội suy Thiessen; (d) Mạng luới trạm thủy văn tại TPHCM

\section{Kết quả và thảo luận}

\subsection{Kết quả hiệu chỉnh, kiểm định mô hình}

\section{SWAT}

Trên cơ sở phân tích loại bỏ ảnh hưởng của hệ thống hồ chứa và tính sẵn có của số liệu quan trắc lưu lượng dòng chảy trên lưu vực sông Đồng Nai, nghiên cứu lựa chọn giai đoạn hiệu chỉnh, kiểm định cho trạm Phước Hòa, Tà Lài, Tà Pao lần lượt là 1980-1994 (hồ Thác Mơ hoạt động từ giữa năm 1995), 1985-2006, 1980-2000 (hồ Hàm Thuận-Đa Mi vận hành vào năm 2001). Kết quả hiệu chỉnh, kiểm định lưu lượng dòng chảy theo tháng của mô hình SWAT tại ba trạm trên được thể hiện như bảng 3. Qua đó, cho thấy mô hình SWAT mô phỏng lưu lượng dòng chảy ở mức chấp nhận tại cả ba trạm Phước Hòa, Tà Lài và Tà Pao. 


\section{BÀI BÁO KHOA HỌC}

Bảng 3. Hiệu chỉnh, kiểm định lưu luợng dòng chảy theo tháng của mô hình SWAT

\begin{tabular}{llccc}
\hline \multirow{2}{*}{ Trạm } & \multicolumn{2}{c}{ Hiệu chỉnh } & \multicolumn{2}{c}{ Kiểm định } \\
\cline { 2 - 5 } & NSE & PBIAS (\%) & NSE & PBIAS (\%) \\
\hline $\begin{array}{l}\text { Phước Hòa } \\
\text { (hiệu chỉnh: 1980-1986, kiểm định: 1987-1994) }\end{array}$ & 0,72 & $-27,56$ & 0,74 & $-23,16$ \\
$\begin{array}{l}\text { Tà Lài } \\
\text { (hiệu chỉnh: 1985-1995, kiểm định: 1996-2006) }\end{array}$ & 0,77 & $-21,68$ & 0,79 & $-15,97$ \\
$\begin{array}{l}\text { Tà Pao } \\
\text { (hiệu chỉnh: 1980-1990, kiểm định: 1991-2000) }\end{array}$ & 0,70 & $-20,75$ & 0,77 & $-15,50$ \\
\hline
\end{tabular}

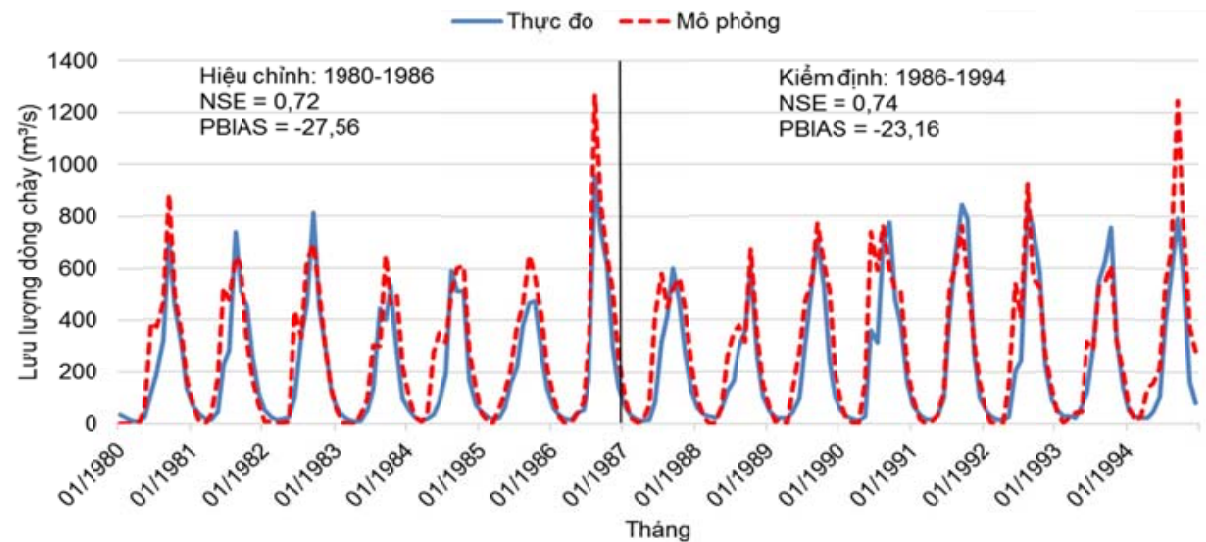

Hình 7. Lưu lương dòng chảy theo tháng tại trạm Phước Hòa (1980-1994

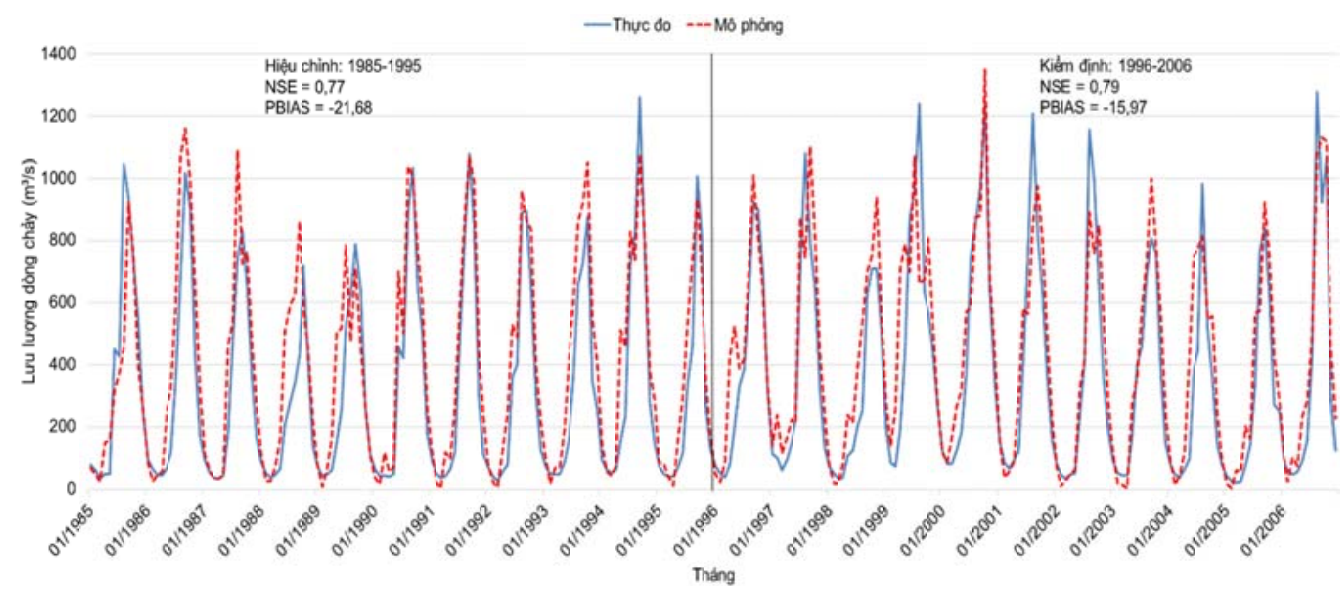

Hình 8. Luu lương dòng chảy theo tháng tại trạm Tà Lài (1985-2006)

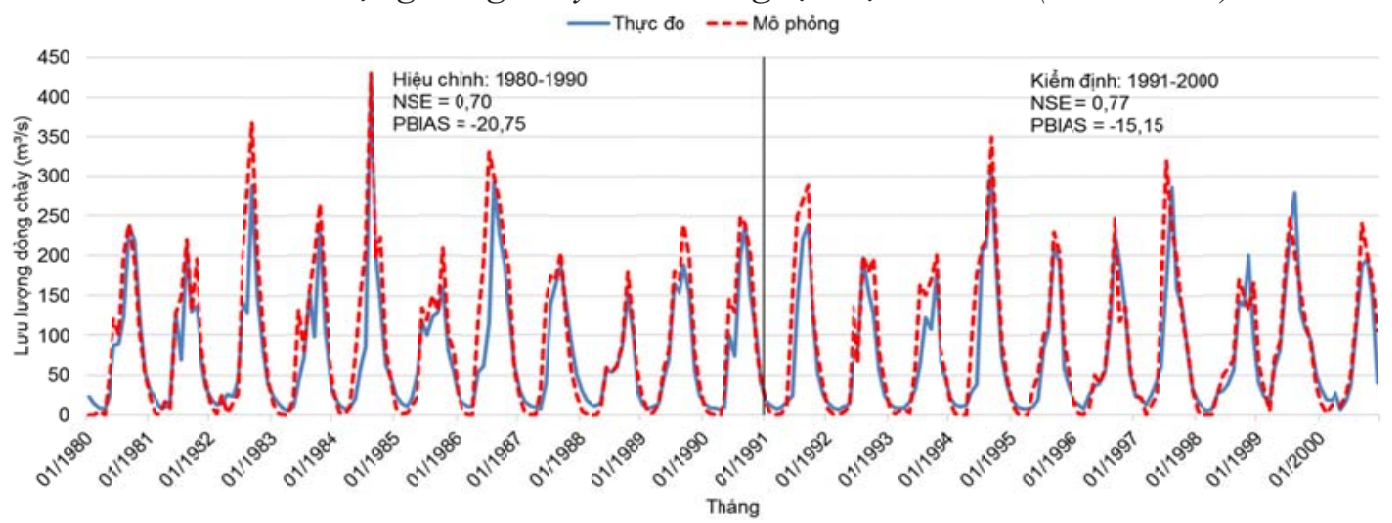

Hình 9. Lưu lượng dòng chảy theo tháng tại trạm Tà Pao (1980-2000) 
3.2. Kết quả hiệu chỉnh, kiểm định về mục nước, độ mặn của mô hình HEC-RAS

Trên cơ sở phân tích tính sẵn có của số liệu quan trắc mực nước tại TPHCM, nghiên cứu tiến hành hiệu chỉnh, kiểm định mực nước theo tháng của mô hình HEC-RAS tại hai trạm Phú An, Nhà Bè lần lượt là 1990-1997, 1998-2006. Kết quả hiệu chỉnh, kiểm định mực nước tại trạm Phú An đều tốt với giá trị NSE lần lượt là 0,78 và 0,73 . Tương tự, tại trạm Nhà Bè, giá trị NSE của mực nước cho giai đoạn hiệu chỉnh, kiểm định đều tốt, lần lượt là 0,77 và 0,72 .

Đối với độ mặn, do giới hạn về dữ liệu nên nghiên cứu tiến hành hiệu chỉnh, kiểm định độ mặn theo ngày của mô hình HEC-RAS tại hai trạm Phú An, Nhà Bè lần lượt trong các tháng 24/2006 và 5-7/2006. Kết quả hiệu chỉnh, kiểm định độ mặn tại trạm Phú An đều tốt với giá trị NSE lần lượt là 0,69 và 0,68 . Tương tự, tại trạ Nhà Bè, giá trị NSE của độ mặn cho giai đoạn hiệu chỉnh, kiểm định ở mức chấp nhận, lần lượt là 0,56 và 0,51 .

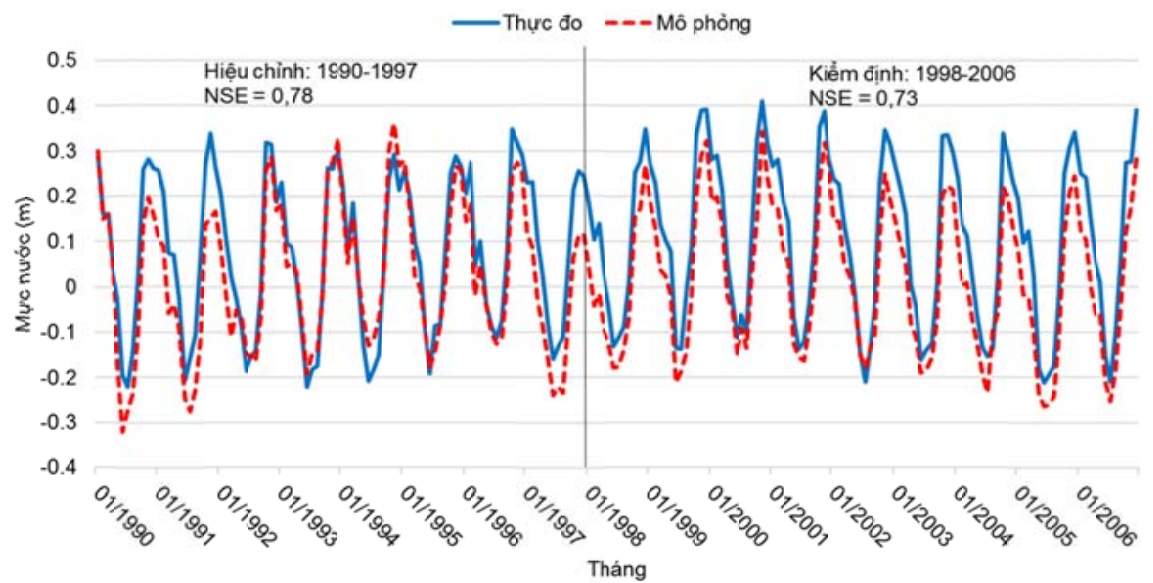

Hình 10. Mưc nước theo tháng tại trạm Phú An (1990-2006)

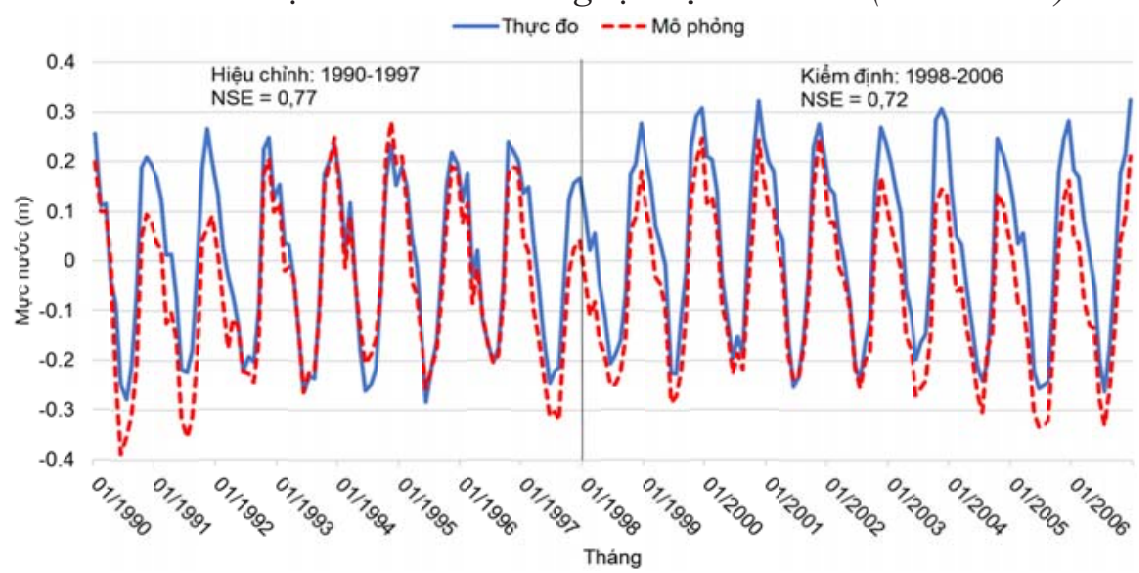

Hình 11. Mục nước theo tháng tại trạm Nhà Bè (1990-2006)

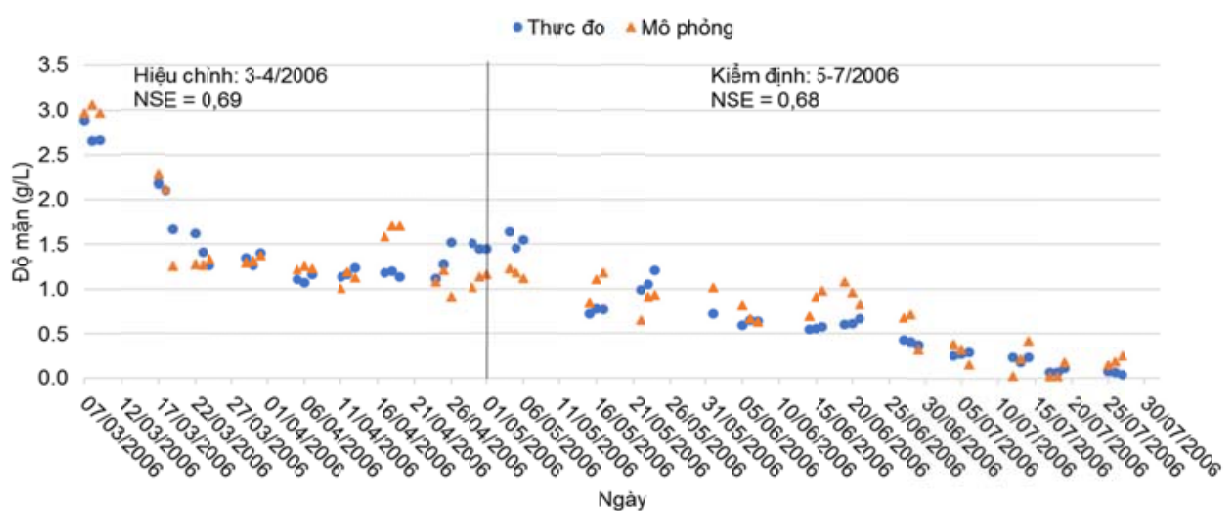

Hình 12. Độ mặn theo ngày tại trạm Phú An trong năm 2006 


\section{BÀI BÁO KHOA HỌC}

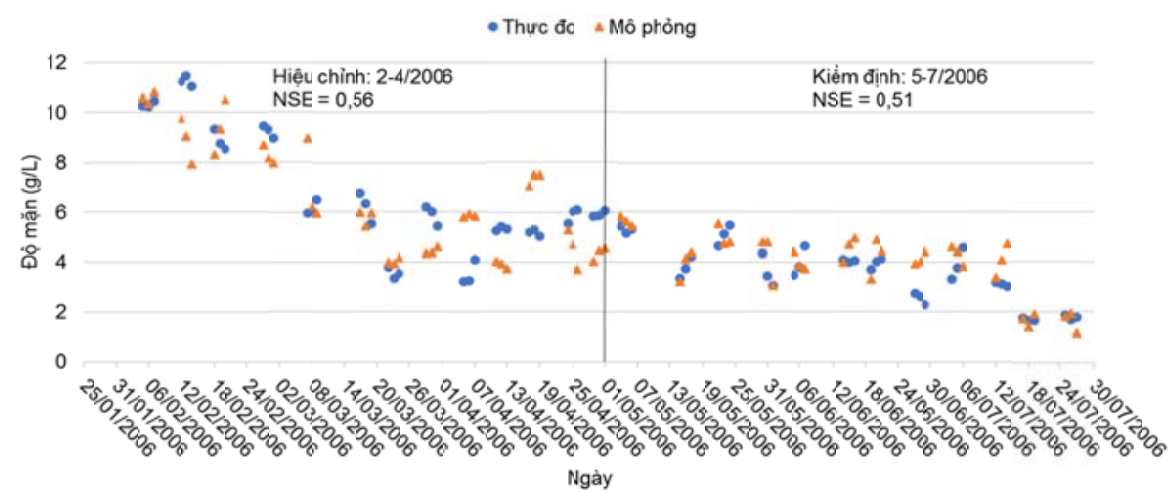

Hình 13. Độ mặn theo ngày tại trạm Nhà Bè trong năm 2006

3.3. Xu hướng độ sâu ngập lụt, độ mặn theo hiện lần lượt như Hình $14 \mathrm{c}$ và d. Theo đó, có thể

\section{thòi gian}

Kết quả phân tích xu hướng độ sâu ngập lụt trong giai đoạn 1980-2006 và kịch bản $\mathrm{BĐKH}$ RCP 4.5 2016-2035 được thể hiện lần lượt như hình $14 \mathrm{a}$ và $\mathrm{b}$. Tương tự, kết quả phân tích xu hướng độ mặn trong giai đoạn 1980-2006 và kịch bản BĐKH RCP 4.5 2016- 2035 được thể

(a)

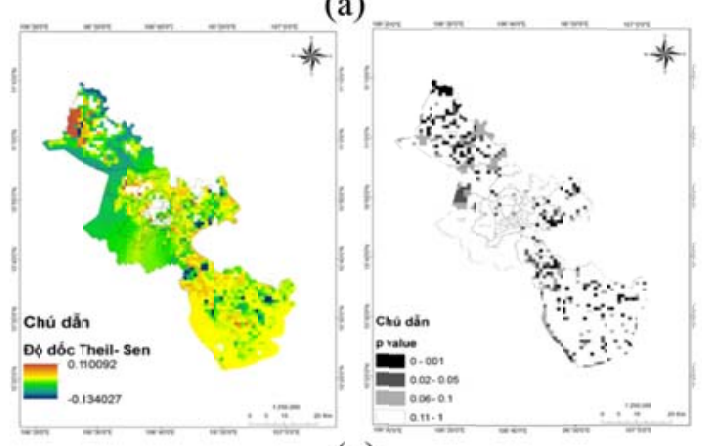

(c)
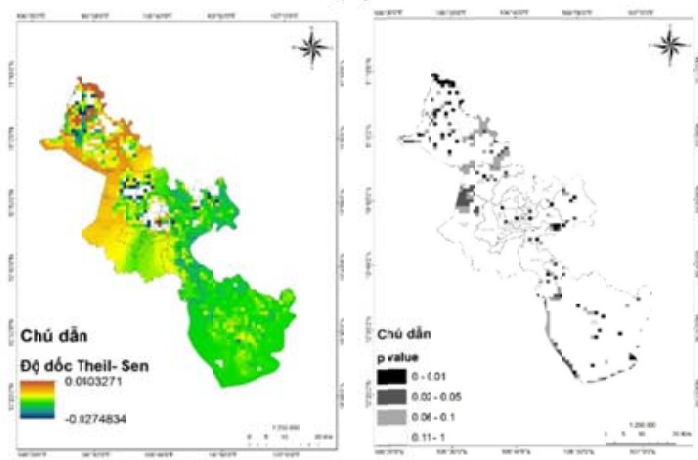
thấy ngập lụt, xâm nhập mặn chủ yếu có xu giảm hoặc không đổi trong giai đoạn 1980-2006. Tuy nhiên, ở kịch bản BĐKH RCP 4.5, cả hai hiện tượng này có xu hướng tăng mạnh tại các khu vực ven sông, kênh rạch từ phía Nam TPHCM dần lên phía Bắc. Đặc biệt, huyện Cần Giờ là khu vực bị ảnh hưởng nặng nề nhất.

(b)

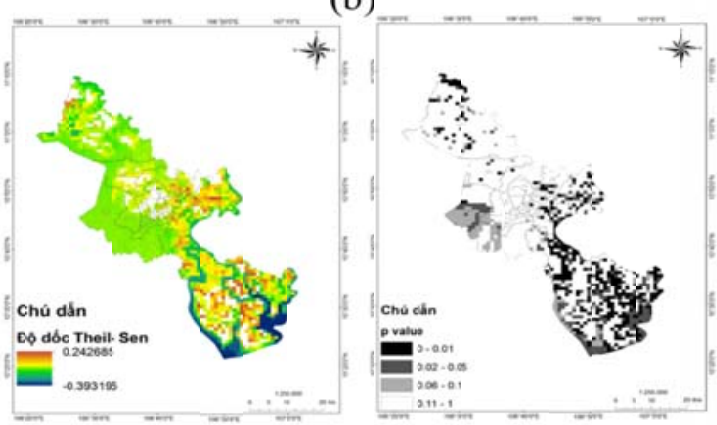

(d)

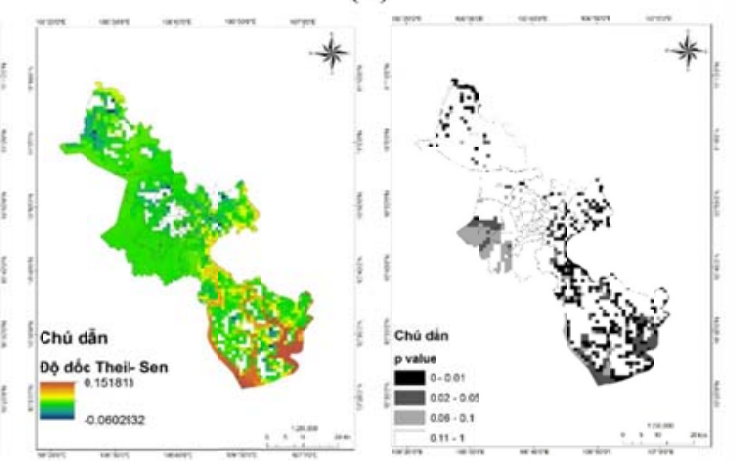

Hìn 14. (a) Xu huớng độ sâu ngập lụt (1980 - 2006); (b) Xu huớng độ sâu ngập lụt (2016 - 2035, RCP 4.5); (c) Xu hưóng độ mặn (1980 - 2006); (d) Xu huớng độ mặn (2016 - 2035, RCP 4.5)

3.4. Phân vùng biến đổi khí hậu theo $x u$ hướng độ sâu ngập lụt, độ mặn

Kết quả phân vùng $\mathrm{BĐKH}$ dựa trên xu hướng độ sâu ngập lụt với ý nghĩa thống kê đi kèm cho từng kịch bản được thể hiện lần lượt trong Hình $15 \mathrm{a}$ và $\mathrm{b}$. Tương tự, kết quả phân vùng $\mathrm{BĐKH}$ dựa trên xu hướng độ mặn với ý nghĩa thống kê đi kèm cho từng kịch bản được thể hiện lần lượt như hình $15 \mathrm{c}$ và $\mathrm{d}$. Theo đó, có thể thấy ngập lụt, xâm nhập mặn chủ yếu có xu hướng không rõ rệt hoặc ít rõ rệt trong giai đoạn 1980-2006. Tuy nhiên, ở kịch bản BĐKH RCP 4.5, cả hai hiện tượng này có tỉ lệ xu hướng rõ rệt hoặc rất rõ rệt gia tăng tại các khu vực ven sông, kênh rạch từ phía Nam TPHCM dần lên phía Bắc. Đặc biệt, huyện Cần Giờ là khu vực bị ảnh hưởng nặng nề nhất. 

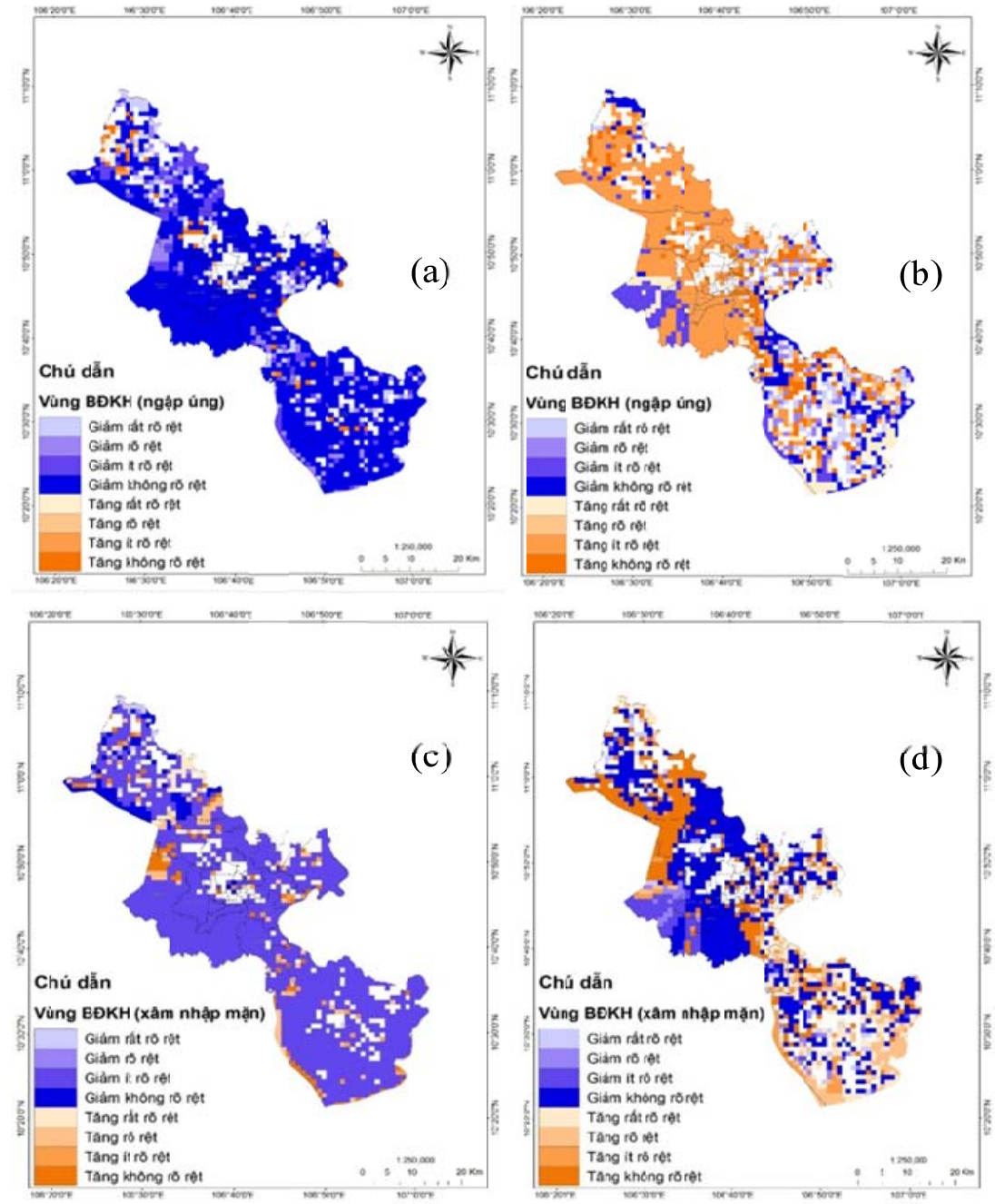

Hình 15. (a) Phân vùng BĐKH theo độ sâu ngập lụt (1980- 2006); (b) Phân vùng BĐKH theo độ sâu ngập lụt (2016- 2035, RCP 4.5); (c) Phân vùng BĐKH theo độ mặn (1980- 2006); (d) Phân vùng BĐKH theo độ mặn (2016- 2035, RCP 4.5)

\section{Kết luận}

Trên cơ sở tích hợp hai mô hình thủy văn SWAT và thủy lực HEC-RAS đã được hiệu chỉnh, kiểm định về lưu lượng dòng chảy, mực nước, độ mặn, nghiên cứu đã cho thấy nếu trong giai đoạn 1980-2006, ngập lụt, xâm nhập mặn chủ yếu có xu hướng không rõ rệt hoặc ít rõ rệt thì sang kịch bản BĐKH RCP 4.5 2016-2035, cả hai hiện tượng này có tỉ lệ xu hướng rõ rệt hoặc rất rõ rệt gia tăng tại các khu vực ven sông, kênh rạch từ phía Nam TPHCM dần lên phía Bắc. Đặc biệt, huyện Cần Giờ là khu vực bị ảnh hưởng nặng nề nhất. Với những phát hiện này, có thể cung cấp thông tin hữu ích cho công tác quản lý, quy hoạch sử dụng đất, thủy lợi, cấp nước trên địa bàn TPHCM trong bối cảnh BĐKH ngày càng diễn biến phức tạp, khó lường.

\section{Tài liệu tham khảo}

1. Abbaspour, K.C., (2015), SWAT-CUP: SWAT Calibration and Uncertainty Programs - A user manual. Eawag: Swiss Federal Institute of Aquatic Science and Technology, pp. 100.

2. ADB (Asian Development Bank), (2010), Ho Chi Minh City-adaptation to climate change. In: Summary Report, Mandaluyong City.

3. Bộ Tài nguyên và Môi trường, (2016), Kịch bản biến đổi khí hậu, nước biển dâng cho Việt Nam. NXB. Tài nguyên - Môi trường và Bản đồ Việt Nam.

4. FAO, (2003), The digital soil map of the world, version 3.6.

5. Gravert, A., (2011), Urban adaptation planning framework: linking climate change action with 


\title{
BÀI BÁO KHOA HỌC
}

planning for sustainable urban development in Ho Chi Minh City. Pacific News, 35, 18-22.

6. IPCC, (2013), Climate Change 2013: The Physical Science Basis Working Group I. Contribution to the Fifth Assessment Report of the Intergovernmental Panel on Climate Change. Cambridge University Press, Cambridge, United Kingdom and New York, NY, USA.

7. Katzschner, A., Waibel, M., Schwede, D., Katzschner, L., Schmidt, M., Storch, H., Eds., (2016), Sustainable Ho Chi Minh City: Climate Policies for Emerging Mega Cities. Heidelberg, Germany: Springer.

8. Moriasi, D.N., Arnold, J.G., Van Liew, M.W., Bingner, R.L., Harmel, R.D., Veith, T.L., (2007), Model evaluation guidelines for systematic quantification of accuracy in watershed simulations. American Society of Agricultural and Biological Engineers, 50 (3), 885-900.

9. N. Downes và các cộng sự (2010), Urban sustainability in times of changing climate: the Case of Ho chi Minh city, Vietnam, 46th ISOCARP Congress 2010.

10. Nguyen Duy Liem và Nguyen Kim Loi (2012), Assessing Water discharge in Be River Basin, Vietnam using GIS and SWAT model, International Symposium on Geoinformatics for Spatial Infrastructure Development in Earth and Allied Sciences 2012, Ho Chi Minh city, Viet Nam, tr. 414420.

11. Nguyễn Kỳ Phùng và Lê Văn Tâm (2011), Nghiên cưu và đánh giá mô hình đánh giá tác động của biến đổi khi hậu đến các yếu tố tụ nhiên, con người, kinh tế -xã hội Tp.HCM.

12. Nguyễn Thị Ngọc Quyên, Nguyễn Duy Liêm và Nguyễn Kim Lợi (2013), Úng dụng gis và mô hình swat mô phỏng lư lương dòng chảy lưu vục sông Srepok, Việt Nam, Hội thảo ứng dụng GIS toàn quốc 2013, chủ biên, Hà Nội, Việt Nam.

13. Rujner, H., Goedecke, M., (2016), Urban water management: spatial assessment of the urban water balance. In: Katzschner A., Waibel M., Schwede D., Katzschner L., Schmidt M., and Storch H., (eds) Sustainable Ho Chi Minh City: Climate Policies for Emerging Mega Cities. Heidelberg, Germany: Springer.

\section{RESEARCH ON APPLICATION OF MODELS FOR TRENDING EVAL- UATION OF FLOOD AND SALINIZATION IN CLIMATE CHANGE CONTEXT. PILOT RESEARCH IN HO CHI MINH CITY}

\author{
Vu Thuy Linh ${ }^{1,2}$, Nguyen Duy Liem ${ }^{3}$, Phan Thi Ha ${ }^{3}$, Ho Minh Dung ${ }^{2,4}$, Nguyen Kim Loi ${ }^{3}$ \\ ${ }^{1}$ Ho Chi Minh City Department of Natural Resources and Environment \\ ${ }^{2}$ Institute for Environment and Resources - Vietnam National University, Ho Chi Minh City \\ ${ }^{3}$ Nong Lam University - Ho Chi Minh City \\ ${ }^{4}$ Institute for Computational Science and Technology
}

Abstract: The study integrated SWAT and HEC-RAS models to simulate and analyze the trends of inundation and saltwater intrusion in Ho Chi Minh City under baseline scenario (1980-2006) and RCP 4.5 climate change scenario (2016-2035). For SWAT model, stream flow was calibrated and validated at an acceptable level at three stream gauges of Phuoc Hoa, Ta Lai and Ta Pao in the Dong Nai river basin. Similarly, for HEC-RAS model, the process of calibration and validation of water level and salinity concentration was done with acceptable levels at two hydrological stations of Phu An and Nha Be in the city. Using the SWAT and HEC-RAS models combined with trend analysis of Mann-Kendall test and Theil-Sen slope, it showed that in the period 1980-2006, inundation and saltwater intrusion mainly tended to be insignificant or minor significant. However, in RCP 4.5 climate change scenario (2016-2035), both of these phenomena would have an increase of major or moderate significant trends in the riverside and canals of the city. Especially, Can Gio district would be the most affected area. With these findings, it can provide useful information for the management and planning of land use, irrigation and water supply in Ho Chi Minh City under unpredictable climate change.

Keywords: Climate change, Flood, HECRAS, Ho Chi Minh City, salinization, SWAT. 